\author{
dr hab. Sławomir KAMOSIŃSKI, prof. UKW \\ Wydział Administracji i Nauk Społecznych, Uniwersytet Kazimierza Wielkiego w Bydgoszczy \\ e-mail: slawomirkamosinski@ukw.edu.pl \\ ORCID: 0000-0001-9314-4991
}

DOI: $10.15290 /$ oes.2019.01.95.08

\title{
DZIEDZICTWO PRZESZLOŚCI (STARE MYŚLENIE) A DETERMINANTY BUDOWY NOWOCZESNEJ FIRMY ${ }^{1}$
}

\begin{abstract}
Streszczenie
Cel - W artykule poruszono kwestię dziedzictwa przeszłości postrzeganego jako kategoria „starego myślenia" i jego wpływu na dzień dzisiejszy i przyszłość firmy.

Opis - Zwrócono uwagę na to, że u progu zmiany własnościowej w Polsce, w 1989 r., kierownicy państwowych przedsiębiorstw dziedzictwo przeszłości firm, którymi kierowali, zmuszeni byli odkreślić zazwyczaj grubą linią. Nie mogli oni w działalności zarządczej odwoływać się do własnych doświadczeń i wykazać się w swojej biografii tym, że są „świadkami pomyłek”. W związku z powyższym, proces zmiany własnościowej i w jego następstwie modernizacji przedsiębiorstw, w tym ich struktury organizacyjnej, sposobu zarządzania i organizacji pracy w wielu przypadkach był opóźniany, a dla części z nich zakończył się ogłoszeniem upadłości. Tylko nieliczne przedsiębiorstwa, które radykalnie zerwały z dziedzictwem przeszłości i po zmianie własnościowej włączyły się do rynku globalnego, odniosły sukces. W sektorze prywatnym, który kształtował się po 1989 r., przedsiębiorcy, z braku tradycji prowadzenia biznesu, mogli liczyć wyłącznie na własną intuicję i działanie oparte na metodzie prób i błędów. Pod koniec dekady lat dziewięćdziesiątych, młodsze pokolenie przedsiębiorców zyskało możliwość analizy błędów popełnionych przez osoby, które działalność gospodarczą rozpoczęły natychmiast po 1989 r. W ten sposób tworzyło się pokolenie przedsiębiorców tzw. „świadków pomyłek”.
\end{abstract}

Słowa kluczowe: dziedzictwo przeszłości firmy, „świadkowie pomyłek”, prywatyzacja i restrukturyzacja przedsiębiorstw, modernizacja przedsiębiorstw, marka przedsiębiorstwa

\section{THE LEGACY OF THE PAST (THE OLD WAY OF THINKING) AND DETERMINANTS OF CREATION (FORMATION) OF A MODERN COMPANY}

\section{Summary}

Purpose - The paper deals with the subject of the legacy of the past understood as a category of "the old way of thinking" and its impact on the contemporary situation and future standing of the company.

Description - It was pointed out that on the doorstep of ownership transformation in Poland, in 1989, managers of the state-owned enterprises usually distanced themselves from the legacy of the past of the companies they managed. They used a "thick line" policy. In their managerial activitie, they could not refer to their own experiences and prove they were "witnesses of mistakes". As a result of

1 Artykuł wpłyną 16 września 2018 r., zaakceptowano 20 listopada 2018 r.

Article received 16 September 2018, accepted 20 November 2018. 
the above, the process of ownership transformation and, the following modernization of enterprises, including their organizational structure, method of management and work organization, were in many cases delayed, and in many cases ended in the declaration of bankruptcy. Only some enterprises which firmly broke up with the legacy of the past and after ownership transformation joined the global market, managed to succeed. In a private sector that formed after 1989, entrepreneurs, due to the lack of tradition of carrying out business, could only count on their own intuition and act basing on the trial-and-error method. At the end of 1990s a younger generation of entrepreneurs gained a possibility to analyze mistakes committed by people who had started their economic activity just after 1989. Such was the way of formation of a generation of entrepreneurs, so-called: "witnesses of mistakes".

Key words: legacy of the past in a company, witnesses of mistakes, restructuring and privatization of enterprises, modernization of enterprises, company brand

JEL classification: D2, P2

\section{Wstęp}

Współczesne przedsiębiorstwa w starannie opracowanych strategiach rozwoju wybiegają w przyszłość, a dla każdego przedsiębiorcy ważne jest to, aby działania podejmowane dzisiaj przynosiły profity za kilka lat. Niewielu z nich zwraca uwagę na przeszłość firmy. Projektowanie przyszłości nie wyklucza tego, że historia przedsiębiorstwa ma duże znaczenie dla jego funkcjonowania dzisiaj, jednak zazwyczaj traktowana jest przez przedsiębiorców instrumentalnie, jako narzędzie, które można ewentualnie wykorzystać w promocji. Służy ona budowie prestiżu firmy, szczególnie wtedy, gdy zakład istnieje nieprzerwanie od wielu lat. Pozwala na kreowane pozytywnego wizerunku firmy. Odpowiednie zabiegi marketingowe i wybiórcze traktowanie przeszłości firmy, dają możliwość „żonglowania” emocjami klientów i umożliwiają pozyskiwanie ich zaufania. Tak skonstruowana gra przeszłością firmy jest zjawiskiem naturalnym. Przedsiębiorcy wybierający przyszłość, przeszłość firmy postrzegają jak zwrócił uwagę E. Lipiński, w ten sposób, że „...to co było ważne pięćdziesiąt czy sto lat temu, nie jest istotne dziś, tym bardziej że i metody działania muszą się zmieniać!” [Lipiński, 1981, s. 34]. E. Lipiński zauważył istotny niuans: „Trzeba orientować się w przeszłości. Przyszłość wprawdzie nie jest wyznaczana jedynie przez przeszłość (takiego determinizmu nie ma!), ale przeszłość żyje długo, żyje wtedy jeszcze, kiedy mniemamy, że już ja przezwyciężyliśmy” [Lipiński, 1981, s. 34]. Wskazane słowa wypowiedziane w $1981 \mathrm{r}$. wytrzymały próbę czasu. Są one, moim zdaniem, nadal aktualne.

K. Obłój podpowiada współczesnym przedsiębiorcom ,jak zarządzać przeszłościa, radzić sobie z teraźniejszością i tworzyć przyszłość" firmy, zwracając uwagę na to, że przeszłość każdej organizacji, tzw. warunki wyjściowe, kiedy organizacja powstawała jest niewiarygodnie ważna i często wkodowana w logikę działania firmy [Obłój, 2017, s. 18]. Jego zdaniem ważne jest takie zarządzanie przeszłością firmy, 
aby odpowiedzieć na najtrudniejsze pytanie dotyczące tego, „które fragmenty i efekty historii firmy stanowia produktywne tworzywo przyszłości, a które trzeba zniszczyć, wyeliminować lub o nich zapomnieć" [Obłój, 2017, s. 19].

Zwracając uwagę na powyższe wskazówki, w niniejszym artykule poszukuję odpowiedzi na problem zależności pomiędzy dziedzictwem przeszłości firmy i związanym z nim bezpośrednio tzw. starym myśleniem kadry zarządzającej a procesem zmiany własnościowej prowadzonym w Polsce po 1989 r. Interesujące jest to jak historia firmy determinowała decyzje podejmowane współcześnie z myślą o przyszłości. Stare myślenie kadry zarządzającej należy rozumieć jako proces postrzegania rzeczywistości po 1989 r. w kategoriach poprzedniego ustroju gospodarczego, a także jako myślenie w kategorii zachowania dystansu do zmian modernizacyjnych. Wyrażało się w nim niedostosowanie się ówczesnych kierowników państwowych przedsiębiorstw do nowych warunków gospodarowania.

\section{Dziedzictwo przeszłości i „stare myślenie” a proces zmiany własnościowej}

We wstępie, przytoczone uwagi E. Lipińskiego i K. Obłoja są ważne dla zrozumienia procesu zmiany własnościowej, jaka dokonała się w polskiej gospodarce po 1989 r. Przeszłość organizacji, moim zdaniem, pozwala na wydzielenie w 1989 r., dwóch grup przedsiębiorstw, które różni czas powstania firmy, a więc dziedzictwo przeszłości. Pierwszą z nich tworzyły przedsiębiorstwa, które zostały założone do 1945 r. Zakłady te mocą ustawy z dnia 3 stycznia 1946 r. o przejęciu na własność Państwa podstawowych gałęzi gospodarki narodowej przeszły tzw. proces nacjonalizacji. Nie ulega przy tym wattpliwości, że jej celem było, w pierwszej kolejności, zerwanie z przeszłościa firmy, wymazanie jej ze świadomości pracowników tylko po to, aby tworzyć nowe zasady gospodarowania. Nacjonalizacja przedsiębiorstwa wiązała się z powołaniem tzw. socjalistycznego zakładu pracy. Proces odrywania zakładu pracy od jego historii przyspieszyła wprowadzana od 1945 r. zmiana jego otoczenia. Zniknęli prawowici właściciele oraz dawni jego interesariusze, likwidowano instytucje wolnego rynku. Pozostało natomiast wielu pracowników, którzy pamiętali przeszłość zakładu. Gdy odwoływali się oni do przedwojennego lub wojennego pozytywnego dziedzictwa zakładu, w którym pracowali, zazwyczaj byli piętnowani przez tzw. aktyw pracowniczy i znajdowali się pod kontrola służb inwigilujących. W Polsce Ludowej, jeśli już wspominano przeszłość firmy powstałej przed 1945 r., to mogła być ona kreślona w złym świetle. Inne spostrzeżenia, często pozytywne, ówczesną władzę drażniły. O rozmowach pracowników Zakładów Naprawczych Taboru Kolejowego w Bydgoszczy następującej treści notatkę przygotował tajny współpracownik: „W rozmowach robotnicy wracają do czasów okupacyjnych, podkreślając sprawną organizację dostaw materiałowych i organizację pracy. Jeden z pracowników tendrowni bez większego entuzjazmu opowiadał o tym, jak pracował przy rozbudowie kotlarni. Stwierdzał, że Aufsehera prawie nie było widać, on sam z calówką chodził po placu budowy, wybierał materiał jaki był potrzebny, przycinał, zbijał i robota szła nad podziw sprawnie. Teraz z materiałem 
nieraz żmudzi kilka godzin, szukając zmęczy się więcej niż robotą przez cały dzień. Dosłownie nie mieści mu się w głowie, że można stworzyć taki bałagan przez 16 lat po wojnie, w porównaniu z porządkiem, jaki panował na zakładzie w latach wojny 1939-1941” [Teczka obiektowa „Naprawa”..., t. 7].

Dziedzictwo przeszłości, wspominane z nostalgia przez pracowników, skrupulatnie odnotowali aktywiści PZPR w Bydgoskiej Fabryce Kabli, przedwojennym Kablu Polskim. W ich wypowiedziach zderzała się przeszłość kapitalistyczna z socjalistyczną rzeczywistościa gospodarki niedoborów i niedostateczną organizacją pracy. Pamiętający okres międzywojnia pracownik, na zebraniu PZPR wytknął, że „Nie dzieje się u nas dobrze, zdarzają się kradzieże małe i poważne, dyscyplina pracy jest niska, mam na myśli wykorzystanie dnia pracy i dyscyplinę technologiczną. (...) Bałagan, brud i niechlujstwo jest stała cechą naszego zakładu" [Archiwum Państwowe ...]. Z fabryki tej, w latach sześćdziesiątych ubiegłego wieku, płynęło do Komitetu Wojewódzkiego PZPR w Bydgoszczy wołanie doświadczonych pracowników, pamiętających zakład przed 1945 r. o potrzebę jego modernizacji: „Bydgoska Fabryka Kabli nie miała dotychczas szczęścia do wielkich inwestycji. To widać po budynkach i maszynach zakładu, pamiętających w większości wczesny okres swojej prawie 50-letniej historii" [Chamot, 1973, s. 139]. Pozytywne doświadczenia, jako dziedzictwo przeszłości, były długo zachowane w pamięci pracowników i stanowiły kontrast dla decyzji podejmowanych przez władze Polski Ludowej.

Nie zawsze zerwanie z przeszłością firmy po 1945 r. było korzystne dla zakładu. Władze Polski Ludowej przekonały się o tym w przypadku tradycyjnych, powstałych w dziewiętnastym wieku lub okresie międzywojnia marek producentów żywności. Pozostała w świadomości konsumentów marka E. Wedel, jako dopisek do nowej nazwy tego przedsiębiorstwa Zakłady 22 Lipca. Dopisek E. Wedel pozwalał na prowadzenie eksportu sentymentalnego, a rodzimym konsumentom dawał poczucie luksusu. Podobnie pozostały marki Winiary czy Żywiec. Był to swoisty paradoks rzeczywistości Polski Ludowej [Kamosiński, 2014, s. 63-74].

Do drugiej grupy przedsiębiorstw w 1989 r. należały te, dla których historia rozpoczęła się w Polsce Ludowej. W kodzie genetycznym tych przedsiębiorstw był zazwyczaj mit założycielski, wpisany w realizację kolejnego z planów gospodarczych. W tej kategorii przedsiębiorstw wszystko było nowe: historia firmy zgodna $z$ wykładnią ówcześnie rządzącej Polskiej Zjednoczonej Partii Robotniczej, relacje zakładu pracy z otoczeniem, organizacja wewnętrzna przedsiębiorstwa i zatrudniani pracownicy. Bydgoska Fabryka Lodówek Byfuch w Bydgoszczy w micie założycielskim szczyciła się tym, że zakład został uruchomiony na dwa lata przed planowanym terminem jego otwarcia, 1 maja 1953 r. Wzorcową historię miały Zakłady Sodowe w Janikowie. Nowa inwestycja planu sześcioletniego, zbudowana na podstawie radzieckiej licencji, stała się zaczynem miasta socjalistycznego. W mit założycielski tego przedsiębiorstwa, podobnie jak w Nowej Hucie pod Krakowem, wpisano rolę miastotwórczą zakładu [Kamosiński, 2007, s. 54].

Powyższe przykłady nieodparcie kierują uwagę na to, że narzucenie Polsce przez ZSRR tzw. ustroju demokracji ludowej, nacjonalizacja przemysłu i wprowadzenie centralnego planowania w gospodarce, było skierowaniem Polski na drogę myślenia 
kategoriami przeszłości o przyszłości. Przedstawioną tezę broni fakt utrwalania jako przewodniej siły narodu robotników, tzw. pracowników rutynowych. Przewaga w Polsce Ludowej w strukturze zatrudnienia robotników, gdy na Zachodzie Europy w latach siedemdziesiątych ubiegłego wieku rozpoczynał się proces serwicyzacji gospodarki, była klasycznym przykładem hamowania zmian strukturalnych w gospodarce i stanowiła przykład odrzucenia czynników modernizacyjnych, które pojawiły się w gospodarkach wolnego rynku. Energochłonność gospodarki Polski Ludowej, nasilająca się $\mathrm{w}$ latach siedemdziesiątych ubiegłego wieku, gdy na świecie poszukiwano energooszczędnych technologii, symbolizowała stan wiedzy i świadomości modernizacyjnej ówcześnie rządzacych elit politycznych. Zwrócić należy uwagę na brak kapitału. W konsekwencji zbankrutowały zasady gospodarowania, które doprowadziły do niedoborów i nie osiagnięto zapowiadanego celu głównego, którym miało być zwycięstwo socjalizmu nad kapitalizmem.

Zerwanie z przeszłością, które zapoczątkowane zostało przez rząd T. Mazowieckiego w 1989 r., zostało symbolicznie odkreślone przez Premiera ,gruba linią". W sejmowym expose 24 sierpnia 1989 r. T. Mazowiecki powiedział: „Rząd, który utworzę, nie ponosi odpowiedzialności za hipotekę, którą dziedziczy. Ma ona jednak wpływ na okoliczności, w których przychodzi nam działać. Przeszłość odkreślamy grubą linią. Odpowiadać będziemy jedynie za to, co uczyniliśmy, by wydobyć Polskę z obecnego stanu załamania”. Symbolicznie zaznaczona „gruba linia” oddzielająca przeszłość stała się, w moim przekonaniu, rzeczywistością wielu polskich przedsiębiorstw. Po 1989 r., w dobie zmiany własnościowej, nie można było z powodów pragmatycznych, w byłych państwowych przedsiębiorstwach, zachować ciagłości historycznej, czyli dziedzictwa przeszłości. System gospodarki niedoborów w Polsce zbankrutowal, a wraz z nim zdewaluowały się zasady organizacji produkcji i działalności przedsiębiorstw. Wolny rynek i zmiana instytucjonalna pokazały jak wielkim obciążeniem dla przedsiębiorstwa i jego pozycji rynkowej była przeszłość. W większości ówczesnych przedsiębiorstw zerwanie z nią oznaczało powstanie dobrej dla firmy ,pustki historycznej”.

Śledząc doświadczenia innych państw w zakresie modernizacji organizacyjnej i technicznej przedsiębiorstw i ich stałej pogoni za „twórczą destrukcja”, odnotować należy, że w Polsce po 1989 r. zabrakło „świadków pomyłek” [Hampden-Turner, Trompenaars, 2006, s. 171], których wiedza w zakresie funkcjonowania organizacji i popełnione w trakcie pracy błędy, pozwalały na efektywne działanie dzisiaj z myśla o przyszłości. W tym wyjątkowym dla przedsiębiorstw okresie większość menedżerów nie mogła odnieść się do cennej wartości, która jest obecna w japońskiej kulturze prowadzenia biznesu. Przyjmuje się, że człowiek, który długo pracuje w danej firmie, popełnił w przeszłości wiele błędów i dzięki temu może doradzać młodszym pracownikom, jak ich uniknąć [Hampden-Turner, Trompenaars, 2006, s. 171]. Jest on depozytariuszem historii, w której popełnione błędy i ich unikanie z racji doświadczenia pozwoliły zbudować przyszłość firmy. Symboliczna jest wypowiedź S. Honda z 1973 r., który świętując dwudziestą piątą rocznicę swojego koncernu powiedział o własnych osiagnięciach: „(...) to tylko rezultat szeregu błędów, niepowodzeń i strat (...), choć nigdy nie popełniłem dwóch błędów z tego samego 
powodu" [Hampden-Turner, Trompenaars, 2006, s. 171]. Na podobną cechę menedżerów zwrócił uwagę J. Welch. Doświadczenie, rozumiane jako dziedzictwo przeszłości, to umiejętność uczenia się na popełnionych błędach w przeszłości. Menedżer, który nie ma za sobą upadku, porażki utrwala w swojej świadomości stare myślenie i zatraca zdolność do wprowadzania „twórczej destrukcji”. J. Welch napisał: „Czwarta cechą jest prężność. Każdy lider popełnia błędy, potyka się i upada. W wypadku liderów najwyższego szczebla należy zadać pytanie, czy uczą się na błędach, mobilizuja po czym zaczynają działać z nową siła, wiarą i pewnością" [Welch, Welch, 2012, s. 113].

Na przekór oczekiwaniom, w Polsce pojawiła się „niekompetencja cywilizacyjna” dużej grupy kadry kierującej przedsiębiorstwami. Zjawisko to obserwowano również u wielu pracowników. Kierownicy zarządzający byłymi państwowymi przedsiębiorstwami podejmując decyzje po 1989 r. nie mogli nawiązywać, do doświadczeń sprzed 1989 r. i na tej podstawie budować strategię firmy na przyszłość. Jednym z powodów tego faktu było to, że „przeszłość zbankrutowała” i stała się niechcący i mimowolnie obciążającym doświadczeniem. Ono utrudniało dostosowanie się mentalne wielu dyrektorów do wymogów stawianych organizacji przez wolny rynek. J. Chumiński zwrócił przy tym uwagę, że „w systemie tzw. realnego socjalizmu w Polsce zasób kapitału ludzkiego był relatywnie dość niski” [Chumiński, 2010, s. 147]. Była to jedna z głównych przyczyn tego, że ,gospodarka PRL była nie tylko odległa od modelu merytokratycznego, ale również w zakładach nastąpiła niemal całkowita atrofia kapitału społecznego" [Chumiński, 2010, s. 147]. Badania kadr $\mathrm{z}$ wyższym wykształceniem funkcjonujących $\mathrm{w}$ polskim przemyśle pod koniec PRL, pozwoliły na sformułowanie kilku ważnych pytań, na które odpowiedzi udzieliła transformacja gospodarki polskiej po 1989 r.: „Czy takie kadry z wyższym wykształceniem, jakie w większości pracuja w naszych przedsiębiorstwach, są zdolne sprostać wyzwaniom rozwoju i konieczności szybkich zmian technicznych i organizacyjnych?” oraz „Czy jakość ich kwalifikacji i stopień wykorzystania, wiek i staż pracy, którego długość nie zawsze oznacza doświadczenie, kompetencje i mądrość (...) nie stanowią swoistej bariery kwalifikacyjnej mogącej utrudnić szybki postęp we wszystkich wymiarach funkcjonowania przedsiębiorstwa?” [Chumiński, 2010, s. 147]. W tym należy, moim zdaniem, przede wszystkim poszukiwać przyczyn opóźniania, podejmowanej przez kierowników zakładu i jego pracowników, decyzji w zakresie zmiany własnościowej przedsiębiorstwa. E. Dunn zwróciła uwagę, obserwując zachowanie polskich menedżerów po 1989 r., że „inaczej niż na Zachodzie, polscy menedżerowie nie mogli polegać na życiorysach wyszczególniających dotychczasowe dokonania. Ze względu na związki z socjalistyczną przeszłością historie pracy zawodowej wielu z nich miały niewielką wartość. Zamiast tego musieli polegać na przekonaniu, że zewnętrzne ja odzwierciedla zmiany w wewnętrznym ja" [Dunn, 2008, s. 91].

W Polsce odejście kadry kierującej państwowymi przedsiębiorstwami od „starego myślenia” oznaczało, jak trafnie zauważyła E. Dunn, metamorfozę z kierownika na menedżera. Kierownik, symbolizujący okres Polski Ludowej, był biurokratą który zarządzając firma polegał na znajomościach i osobistych kontaktach z pracownikami 
i wikłał się w układy. Menedżer, pożądany nowy typ kadry kierowniczej, był postrzegany jako osoba niezwykle elastyczna i skłonna do zmian. Co więcej, oczekiwano, aby menedżer nie miał doświadczenia, ponieważ „brak doświadczenia jest jednak raczej zaletą niż obciążeniem, oznacza bowiem niezależność i nieuwikłanie w niepożądane układy z ministerstwami i pracownikami" [Dunn, 2008, s. 90]. Zdaniem cytowanej Badaczki „transformacja kierownika w menedżera jest jednym z najważniejszych wymiarów prywatyzacji osób. Ta zaś z kolei, promując ideologię indywidualizmu, staje się rdzeniem transformacji gospodarki socjalistycznej w kapitalistyczną" [Dunn, 2008, s. 93]. Jak ważna była „prywatyzacja osób” oznaczająca, jak wykazano powyżej, odejście od starego myślenia i mentalnego dziedzictwa przeszłości, przekonują badania J. Collinsa. Stwierdza on, cytując jednego z menedżerów, że „nowe technologie, które wprowadzamy, to dwadzieścia procent naszego sukcesu (...) a pozostałe osiemdziesiąt procent zawdzięczamy kulturze naszej firmy" [Collins, 2007, s. 175]. Wskazany Autor podpowiada trafnie, że „przeciętność jest przede wszystkim wynikiem nieudolnego zarządzania, a nie złych technologii” [Collins, 2007, s. 175].

Boleśnie o tym, że to nie technologie decydują o sukcesie gospodarczym i efektywnym wdrożeniu procesów modernizacyjnych do przedsiębiorstw, a odpowiada za to organizacja przedsiębiorstwa, kultura techniczna pracowników i przede wszystkim wola środowiska do wdrażania „twórczej destrukcji”, przekonał się E. Gierek w latach siedemdziesiątych ubiegłego wieku. Nie sprawdziła się w Polsce Ludowej realizacja strategii naśladownictwa. Zakupione zachodnioeuropejskie licencje stały się dla większości pracowników państwowych przedsiębiorstw niechcianym prezentem. Kłopoty z wdrożeniem licencji i niska jakość produktów wytwarzanych przy ich wykorzystaniu, przyspieszyły proces bankructwa socjalistycznego sposobu gospodarowania. Polska nie miała możliwości włączenia się do międzynarodowego podziału pracy. Kraj pozostał peryferyjnym obszarem gospodarczym, oferującym surowce i tanią siłę robocza. Odsetek wyrobów produkowanych na podstawie licencji wynosił w Polsce w 1975 r. 4,2\%, w 1980 r. 5,0\%, a w 1989 r. 1,1\%. W tym samym okresie w Japonii wskaźnik ten kształtował się nieprzerwanie na poziomie około 25\% [Kamosiński, 2009, s. 306]. W skali mikro, pojedynczego zakładu pracy, misja inwestycyjna kierownictwa Zakładów Naprawczych Taboru Kolejowego w Bydgoszczy doprowadziła do tego, że w latach 1975-1976 „dokonano nieuzasadnionych potrzebami zakupów maszyn i urządzeń na sumę około $10 \mathrm{mln}$ zł”. Trafne wydaje się uzasadnienie tego faktu, wprost odnoszace się do cytowanej powyżej uwagi J. Collinsa: „Prawdopodobna przyczyną zaistniałego stanu jest niedostateczne rozeznanie parametrów użytkowych zakupionych maszyn i urządzeń, pobieżna ocena wykorzystania tych środków oraz brak odpowiednich decyzji pozwalających na optymalne wykorzystanie posiadanego majątku trwałego" [Teczkea obiektowa „Naprawa”..., t. 4]. Zawodziła kultura organizacyjna oraz w klasycznej formie obserwowano nieudolne zarządzanie przedsiębiorstwem.

Niekompetencja cywilizacyjna, obserwowana po 1989 r. u załóg i kierownictwa wielu przedsiębiorstw, była zjawiskiem często spotykanym. W Fabryce Automatów Tokarskich w Bydgoszczy w 1992 r. kadra kierownicza, zapewne z powodu przywią- 
zania do starego myślenia kategoriami produkcji globalnej, lekceważyła podstawowe wskaźniki mikroekonomiczne. W 1991 r., w odniesieniu do 1990 r., odnotowano w tym zakładzie spadek produkcji o $50 \%$. W tym samym okresie koszty produkcji obniżono zaledwie o $5 \%$, a wynagrodzenia pracowników wzrosły o $12,6 \%$ [Kamosiński, 2015, s. 213]. Można odnieść wrażenie, że w ten sposób kierownictwo zaklinało rzeczywistość, czekając na powrót odchodzącej epoki Polski Ludowej. Klimat panujący w tym przedsiębiorstwie oddaje wypowiedź sekretarza Rady Pracowniczej. Stwierdził on, że jeśli: „istnieje konieczność powrotu do poprzedniego sposobu działania, to potrafimy dostosować się do wskazówek" [Kamosiński, 2015, s. 213]. Czyżby liczono na cofnięcie reform i przywrócenie „starego porządku”? Podobnie, stare myślenie i ochrona dziedzictwa przeszłości, legły u podstaw sporu jaki wybuchł w Zakładach Chemicznych Zachem w Bydgoszczy. W 1993 r. załoga tego przedsiębiorstwa, głosami $70 \%$ zatrudnionych, odrzuciła propozycję przekształcenia tego zakładu w jednoosobową spółkę Skarbu Państwa. Decyzję uzasadniano obiegową opinią: „nie jest super (...), ale oby nie było gorzej. A inaczej może oznaczać gorzej”. Kierownik Zachemu dodawał: „Znam przykłady z wielkiej polskiej chemii Oświęcimia, Tarnowa czy Kętrzyna, gdzie spółki jednoosobowe (Skarbu Państwa SK) nie okazały się takim miodem. Bo niby jest to część tej wielkiej prywatyzacji, ale jakaś taka niedorobiona, niedokończona. Profitów, ulg podatkowych nie ma z tego do tej pory żadnych, dywidenda jest jaka była. Uproszczone zarządzanie też jawi się jako iluzja. Nie ma rad pracowniczych, ale są rady nadzorcze - o tyle nieudolne, o ile pochodzące spoza zakładu i nie bardzo interesujące się jego losem. Ot biora pieniądze za posiedzenia i wciąż chcą udowadniać, że są ważniejsi od dyrektora" [Na ścięzre do prywatyzacji..., 1993, s. 8]. Bariera mentalna była trudna do pokonania.

Poszukiwanie przyczyn upadłości Zakładów Rowerowych Romet w Bydgoszczy prowadzi w pierwszej kolejności do wskazania na niekompetencję cywilizacyjną ówczesnych kierowników tej firmy. Rzeczywistość gospodarczą po 1989 r. postrzegali oni przez pryzmat dziedzictwa przeszłości, od którego nie chcieli odejść. Brak woli restrukturyzacji firmy, podniesienia jej efektywności hamował modernizację struktury wewnętrznej firmy, zmianę organizacji produkcji, przebudowę mentalności. Z. Sosnowski, producent rowerów, a w latach dziewięćdziesiątych handlujący rowerami z Rometu, wspominał, że „stare myślenie” i zapatrzenie menedżerów w sukcesy zakładu z epoki PRL widoczne było między innymi w skostniałej strukturze organizacyjnej firmy: „Proszę pokazać mi firmę, która produkuje wszystko sama. Żeby robić np. piasty, trzeba ich produkować miliony, wtedy są odpowiednio tanie i odpowiednio dobre. Tymczasem Romet nie mógł się skupić na detalach, bo musiał ogarnąć cała gigantyczną produkcję" [Kostrzewski, Miączyński, 2012, s. 47]. Jako inny przykład starego myślenia podał: „Później (Romet - wpis SK) zaczał eksperymentować z lżejszymi, aluminiowymi ramami. Miały taką strasznie brzydką naklejkę Romet. Sprzedawały się fatalnie. (...) Kiedyś odwiedził nas dyrektor handlowy Rometu i zapytał o te aluminiowe rowery. Zaproponowałem mu wtedy, żeby zdjąć te brzydkie naklejki i nakleić cokolwiek obco brzmiącego np. Voyager zamiast Romet. Trudno było mu to przełknąć, ale ja ten eksperyment przeprowadziłem" [Kostrzewski, Miączyński, 2012, s. 48]. 
Problem niekompetencji cywilizacyjnej załogi i jej utkwienia mentalnego w starym myśleniu, zakorzenionym w dziedzictwie przeszłości, dał o sobie znać w Fabryce Lin i Drutu Drumet we Włocławku, gdy wybuchł w tym zakładzie konflikt z menedżerem, który reprezentował już zapewne grupę tzw. sprywatyzowanych menedżerów. Po przekształceniu 17 kwietnia 1991 r. fabryki w jednoosobowa spółkę Skarbu Państwa, istniejące w niej trzy związki zawodowe zarzucały Prezesowi Spółki Drumet SA, że: „załoga jest doprowadzona do kresu wytrzymałości psychicznej, na skutek stalinowskich metod zarządzania firmą”. W dalszej części podano: „Pracownicy są zastraszeni przez ciagłe nagonki, nieuzasadnione kontrole, które przypominają nam stan wojenny". W kolejnych zdaniach pracownicy donosili: „Sądziliśmy, że prywatyzacja naszego zakładu przyczyni się do normalności w funkcjonowaniu przedsiębiorstwa i w unormowaniu stosunków społecznych. Tymczasem mamy do czynienia z wdrażaniem dziewiętnastowiecznego kapitalizmu, co nie rokuje nadziei dla prywatyzacji o szerszym zasięgu”. „Sprywatyzowany Prezes” Drumetu w liście z 14 października 1991 r. skierowanym do Ministra Przekształceń Własnościowych stwierdził: „Wyjaśniam, że Drumet jak większość przedsiębiorstw państwowych był obciążony wielkimi wadami jeżeli chodzi o działalność. Pewna część załogi była znacznie rozpolitykowana. Szukała ona taniej sensacji, a nie rzetelnej pracy. Nadto nie istnieje jeszcze do tej chwili system odpowiedzialności za podejmowane decyzje na średnim stopniu zarządzania. Nie istniała kontrola dyscypliny pracy i odpowiedzialności pracowniczej. Przedsiębiorstwo typu socjalistycznego wytworzyło monstrualny schemat organizacyjny skutecznie wymazujący jakąkolwiek możliwość kontroli nad działaniami poszczególnych pracowników. Kwitł też na znaczną skalę zabór mienia, a także kumoterstwo i pijaństwo (...). Stwierdzam, że poprawa tego stanu rzeczy powinna prowadzić, między innymi, przez gruntowna przebudowę schematu organizacyjnego przedsiębiorstwa, precyzyjne określenie uprawnień i obowiązków poszczególnych pracowników na swych stanowiskach pracy" [Archiwum Ministerstwa Skarbu, Fabryka Lin i ...]. Przywracanie podstawowych obowiązków pracowników świadczących pracę, burzenie wypracowanych przez lata działalności tej firmy systemów zależności i podległości pracowników przez wdrażanie nowej struktury organizacyjnej firmy wywoływało naturalny opór. Podniesienie efektywności i modernizacja przedsiębiorstwa jako cel zmiany własnościowej zderzyły się w tym zakładzie z mentalnym dziedzictwem przeszłości. Zwracając uwagę na powyższy przypadek odnotować należy to, że tzw. sprywatyzowani menedżerowie wskazywali na dodatkowy problem blokady modernizacyjnej polskich przedsiębiorstw po 1989 r. Identyfikowano go przez pryzmat prawa własności i poczucia odpowiedzialności za własność: ,istnienie zamiast rzeczywistego, aktywnego właściciela zainteresowanego rozwojem, właściciela zastępczego - instytucji reprezentującej państwo" [Kamosiński, 2015, s. 215]. Właściciel zastępczy, jakim było państwo, zarządzał przedsiębiorstwem przez rozbudowaną biurokrację, która niechętna była wprowadzaniu zmiany własnościowej. Było to równoznaczne z utratą przez tę grupę wielu przywilejów i wpływów.

Bydgoskie Zakłady Chemii Gospodarczej Pollena w Bydgoszczy są przykładem udanej prywatyzacji kapitałowej. Mentalna „prywatyzacja menedżerów” umożliwiła 
przeprowadzenie skutecznej zmiany własnościowej. Dyrektor tego zakładu przedstawił załodze bariery hamujące rozwój firmy i jej modernizację. Pierwsza, według niego, była bariera dystrybucji, druga - bariera konkurencji, trzecia - bariera technologii produkcji. Dyrektor, wchodząc w rolę menedżera stwierdzał: „W obecnych warunkach istotnym problemem staje się bariera popytu, która w warunkach dużej konkurencji na rynku wyrobów chemii gospodarczej wymusza zmianę w podejściu do szeroko pojętej problematyki handlu. Konieczne jest tworzenie stabilnych kontaktów z nabywcami, elastycznej polityki cenowej oraz stosowanie urozmaiconych technik sprzedaży. W tej dziedzinie kryją się jednocześnie duże możliwości (ekspansja) i zagrożenia (eliminacja z rynku). Wykorzystanie możliwości i przeciwdziałanie zagrożeniom zależy tylko od przedsiębiorstwa" [Archiwum Ministerstwa Skarbu Państwa, Wniosek ...]. Szkolenia załogi celem wyjaśnienia jej zasad wolnego rynku i w ślad za tym idące rozmowy kierownictwa z potencjalnymi inwestorami, którymi były firmy Unilever, Henkel, Benckiser, pozwalały wyszukać najlepszego kandydata dla tego zakładu. Wybrano, jako inwestora strategicznego, firmę Unilever z Holandii. Zbycie przez Skarb Państwa części akcji Polleny na rzecz firmy Unilever nastąpiło 17 czerwca $1991 \mathrm{r}$. W pierwszym kroku nowy właściciel zerwał więź ze stara marką Bydgoskie Zakłady Chemii Gospodarczej Pollena w Bydgoszczy. Ustanawiając nową markę Lever Polska w Bydgoszczy, menedżerowie kierujący tym zakładem wysłali sygnał, że całkowicie zerwali z przeszłością firmy. Stare myślenie ustępowało orientacji prorynkowej. Po zmianie własnościowej dyrektor tej firmy powiedział „To dla nas ogromna szansa. Nowy właściciel daje nam możliwość zintensyfikowania produkcji. Będziemy wytwarzać 80 tys. ton proszków detergentowych, czyli dwa razy więcej niż dzisiaj. Przygotujemy też na rynek nowy hit. Będą to płynne środki piorące" [Kunach, 1991, s. 18]. W następstwie podjętych inwestycji przez nowego właściciela Lever Polska SA, fabryka w Bydgoszczy zaczęła odgrywać ważną rolę w europejskiej strategii zaopatrzenia Unilevera. W okresie zaledwie pięciu lat od podjęcia decyzji o przekształceniu się w jednoosobową spółkę Skarbu Państwa (1990 r.) i sprzedaży akcji inwestorowi strategicznemu Unilever, marka Lever Polska SA stała się znanym w kraju producentem proszków do prania. Symbolem sukcesu rynkowego tej firmy była jedna z najsłynniejszych w Polsce kampanii reklamowych proszku do prania sprzedawanego pod marką handlowa „Pollena 2000”. Reklama ta, nawiązując bezpośrednio do tradycji historycznych Rzeczpospolitej Szlacheckiej, stała się jednym z symboli nowoczesnej formy sprzedaży dóbr konsumpcyjnych. Była ona także zwiastunem ewolucji polskiego konsumenta, który z klienta łowcy poszukującego produktów w latach Polski Ludowej, stał się klientem dokonującym świadomego wyboru. Proces modernizacji świadomości konsumentów, wydaje się, następował szybciej niż zmiana mentalności pracowników.

Charakterystycznym przykładem zerwania z przeszłością i starym myśleniem celem ratowania firmy przed upadłościa jest przypadek Zakładów Naprawczych Taboru Kolejowego w Bydgoszczy. Zakład ten, włączony do Narodowych Funduszy Inwestycyjnych w 1996 r., został w 1998 r. sprzedany grupie jego byłych kierowników. Był to typowy wykup menedżerski, o którym w następujący sposób mówił 
jeden z byłych kierowników: „Podjęliśmy próbę uratowania go przed przejęciem. Zostało zorganizowane spotkanie $\mathrm{z}$ załoga. Inaczej niż w wielu innych firmach, związki zawodowe przychyliły się do opcji, że nie będzie to wykup przez całą załogę, lecz przez menedżerów" [Nowoczesny tabor..., 2007].

Po wykupie menedżerskim ZNTK Bydgoszcz z Narodowych Funduszy Inwestycyjnych, właściciele firmy przeprowadzanie restrukturyzacji płytkiej skorelowali z jej restrukturyzacja głęboką. Była to bardzo odważna decyzja Zarządu, oceniana jako ryzykowna, brawurowa i trudna. Restrukturyzacja głęboka polegała na podjęciu przez Zarząd dwóch zasadniczych kroków: reorganizacji rynków zbytu i rozszerzenia asortymentu produkcji. Zapoczątkowano w ten sposób modernizacje zakładu w zakresie organizacji produkcji, jego struktury wewnętrznej i przede wszystkim zmiany postrzegania pracy i jej świadczenia przez pracobiorców. Proces modernizacji firmy miał odbywać się przy zachowaniu głównego profilu jej działalności, jakim były remonty taboru kolejowego. Reorganizacja rynków zbytu była działaniem wynikającym z bardzo słabo rokującego rynku wewnętrznego, na którym praktycznie monopolistą były Polskie Koleje Państwowe. Głównie ta przyczyna wymusiła rozszerzenie rynku zbytu o Ukrainę. Współpraca z tym państwem polegać miała na modernizacji i budowie dla tego partnera wagonów pasażerskich. Zakład zdobył również kontrakt na dostarczenie wagonów dla kolei rosyjskich. W roku 1999 bydgoska spółka pozyskała jeszcze jeden dla niej istotny kontrakt. Podpisano umowę z Niemcami na remont lokomotyw spalinowych. Było to otwarcie się ZNTK Bydgoszcz na bardzo wymagający, a zarazem stabilny $i$ intratny rynek.

Drugim zadaniem modernizacyjnym było rozszerzenie oferty produktów firmy. Obok remontów taboru kolejowego zdecydowano się na jego produkcję. Podjęto prace koncepcyjne nad małym i ekonomicznym autobusem szynowym (szynobus). Pojazdy te miały kursować na lokalnych, o niskiej frekwencji, trasach kolejowych. Równolegle prowadzono prace badawcze i koncepcyjne nad własna, oryginalną konstrukcją tramwaju. Decydując się na wprowadzenie nowego profilu produkcji, właściciele bydgoskiej firmy wykazali się umiejętnością, którą P.F. Drucker, określił w następujący sposób: „patrzeć na możliwości w szerokim zakresie” i pytać „Która z tych możliwości pasuje do mnie, do tej firmy, angażuje to, w czym jesteśmy dobrzy i do czego wykazaliśmy praktyczne zdolności” [Drucker, 2004, s. 161].

Równie ważna jak restrukturyzacja firmy i zmiana własnościowa była zmiana jej nazwy. Zakłady Naprawcze Taboru Kolejowego w Bydgoszczy 17 sierpnia 2001 r. zmienily ja na Pojazdy Szynowe PESA Bydgoszcz SA. Prezes Zarządu PESA Bydgoszcz S.A. T. Zaboklicki w następujący sposób uzasadnił tę decyzję: „Nasza firma była odbierana jako jedno z najgorszych polskich przedsiębiorstw i do tego dysponowała kapitałem na poziomie zera" [Kamosiński, 2013, s. 27]. Zmiana nazwy to, podobnie jak w przypadku firmy Lever Polska, zmiana wizerunku firmy. Rozpoczęto tym samym żmudny proces kreowania na rynku nowej marki producenta pojazdów szynowych, na którym główne miejsca zajęły renomowane firmy: Bombardier, Siemens, Skoda. O tym kroku przesądziła również potrzeba zwrócenia uwagi klientów na nowy profil produkcji firmy. 
Należy wziąć po uwagę także to, że zmiana nazwy firmy to zabieg celowy, podparty dążeniem do natychmiastowego symbolicznego zerwania przez właścicieli PESA Bydgoszcz SA z niechlubną tradycją przedsiębiorstwa, w którym jak w soczewce skupiły się wszystkie wady minionej epoki Polski Ludowej. Odrzucenie przeszłości było decyzją dla przyszłości. $\mathrm{Na}$ ten problem zwracał uwagę W. Olins, który stwierdził: „kiedy jednak stara nazwa zostaje skompromitowana (...) trzeba zastosować grubą kreskę i zaczać wszystko od nowa" [Olins, 2009, s. 56]. W kwietniu 2011 r. Prezes Zarządu PESA Bydgoszcz S.A. T. Zaboklicki powiedział: „A pozycja lidera wśród polskich producentów taboru (...) to świadomość, że inne firmy starają się iść naszą droga. Mobilizują się do rywalizacji, podpatrują nas, budują pojazdy w ślad za nami. To PESA zbudowała pierwszy niskopodłogowy tramwaj w Polsce, ale dziś już nie jedyny. To PESA zaproponowała klientom pierwsze nowoczesne polskie zespoły trakcyjne, ale dziś chca je budować - i już buduja - nasi konkurenci. Pozycja lidera nie upoważnia do popadania w samozadowolenie" [Szanijac tradycje..., 2011, s. 24]. Ucieczka menedżerów od stanu samozadowolenia to podążanie w kierunku „twórczej destrukcji” i budowania na bazie doświadczeń przeszłości, w danej chwili, przyszłości firmy.

\section{Dziedzictwo przeszłości jako szansa na modernizację sektora prywatnego $\mathrm{w}$ gospodarce}

Sektor prywatny w gospodarce polskiej, który rozwijał się od połowy lat siedemdziesiątych, a intensywnie zaczął się budować po 1989 r., przyciagał przede wszystkim osoby kreatywne, wierzące $\mathrm{w}$ wolny rynek. Zakładane od podstaw biznesy, w początkach lat dziewięćdziesiątych ubiegłego wieku, mają w roku 2018 krótką historię postrzegana $\mathrm{w}$ kategorii dzieje firmy. Przedsiębiorcy natomiast zdobyli w tym okresie pokaźny bagaż doświadczeń. Stali się „świadkami własnych pomyłek". Wskazane dziedzictwo przeszłości, doświadczenie biznesowe przedsiębiorcy prywatnego nie musiało być odkreślane, jak w przypadku kierowników państwowych przedsiębiorstw, symboliczna ,gruba linią". Ono stanowiło o sile i pozycji marki, którą przedsiębiorca zbudował. Dziedzictwo przeszłości tej grupy osób prowadzących własne firmy obejmuje współcześnie doświadczenia związane ze zmianą instytucjonalną w Polsce, ewolucją otoczenia firmy, zmianami legislacyjnymi.

Polscy przedsiębiorcy, budując własne firmy w 1989 r., zazwyczaj nie mieli żadnych doświadczeń w zakresie prowadzenia działalności gospodarczej na własny rachunek. Nie dane im było obserwowanie innych przedsiębiorców i uczenie się na ich błędach. Nauka zasad wolnego rynku dla wielu z nich była bolesna. W Polsce brakowało „świadków pomyłek”. Metoda prób i błędów była jedynym sposobem na budowanie przez przedsiębiorcę własnego kapitału wiedzy i doświadczenia, który w konsekwencji pozwalał mu na przyjęcie po latach działalności gospodarczej tytułu „świadka pomyłek”. Młodsza grupa przedsiębiorców, zakładająca działalność gospodarczą pod koniec lat dziewięćdziesiątych ubiegłego wieku, miała już okazję do tego, aby uczyć się na błędach innych. I. Klaja tak wspomina ten proces: „my po 
przeanalizowaniu ich porażek potrafiliśmy otworzyć się na to, że coś robimy źle. I posłuchać lepszych od siebie" [Klaja, 2017, s. 22].

Współcześnie, po dwóch dekadach budowy wolnego rynku i zbieraniu doświadczeń przez przedsiębiorców i menedżerów, K. Obłój podpowiada, że „historia firmy ma niesamowicie ważne znaczenie i swoje stałe echo w teraźniejszości. Jest obecna w systemach zarządzania ludźmi, w strukturach, w procesach, w wyborach produktów, usług i rynków, w kryteriach inwestycyjnych, w sposobach traktowania dostawców - praktycznie prawie we wszystkim. Wiele z tych rozwiązań jest pochodną norm i wartości założycieli, pierwszych wyborów lub warunków wyjściowych w otoczeniu" [Obłój, 2017, s. 24]. Zdaniem cytowanego Autora historia firmy, jej dziedzictwo przeszłości może być „produktywnym tworzywem przyszłości”, lecz "Jeśli się nie zna i nie rozumie przeszłości organizacji i jej otoczenia, to zbudowanie przyszłości jest bardzo trudne" [Obłój, 2017, s. 19].

Otwartym pozostaje także rozterka, która dotyka wszystkich właścicieli i menedżerów, a związana jest z pytaniem, jak długo kierować firmą. Każdy menedżer i właściciel przyzwyczaja się do rozwiązań, które przyniosły określone zyski i profity w przeszłości i uznaje je za doskonałe. Osobiste przekonanie właściciela czy menedżera, że stworzył perfekcyjną strukturę, organizację, czy wdrożył doskonały sposób zarządzania, który nie wymaga korekt, może być pułapka, w którą nieświadomie wprowadza się firmę. To dziedzictwo przeszłości potencjalnie może oznaczać uwięzienie świadomości przedsiębiorcy w kategorii postrzegania dnia dzisiejszego firmy przez pryzmat „perfekcyjnego dziedzictwa przeszłości”. Samozadowolenie z perfekcyjnie działającej organizacji sprawia, że brakuje przedsiębiorcy miejsca na refleksję nad schumpeterowską „twórczą destrukcją” i szybkiego, elastycznego odpowiadania na zmiany, które dyktuje rynek.

Zdaje się, że ten problem jest trudny do dostrzeżenia przez przedsiębiorców i menedżerów w codziennym prowadzeniu biznesu i niewielu z nich posiadło zdolność do krytycznego myślenia o organizacji, którą stworzyli. I. Klaja, właściciel marki 4F mówi, że niebezpieczne dla firmy i pozycji jej marki na rynku jest to, że dominuje w niej przez bardzo długi okres długoletni właściciel i jego zdanie jest rozstrzygające. Na bazie zebranych doświadczeń uważa on, że należy brać pod uwagę to, że właściciel i założyciel to „osoba, która tak przyzwyczaiła się do swoich sukcesów, że brakuje jej pokory by coś zmienić" [Klaja, 2017, s. 24]. Na własnym przykładzie ilustruje on ten problem w następujący sposób: „W przypadku marki sportowej bardzo ważne jest, by nie zestarzała się razem z zarządem. To kluczowe w kontekście 4F, bo ja mam już 40 lat, a w Polsce niewiele osób w okolicach pięćdziesiątki aktywnie uprawia sport. Muszę z pokorą słuchać młodszych od siebie ludzi. Nawet, jeśli nie zawsze podobają mi się ich pomysły, projekty ubrań, często okazuje się, że się sprawdzają" [Klaja, 2017, s. 26].

Dziedzictwo przeszłości i bycie „świadkiem pomyłek” podpowiada, że w historii każdej firmy, która intensywnie się rozwija, pojawia się moment w którym jej właściciel, aby umożliwić firmie dalszą ekspansję rynkowa, musi, patrząc w przyszłość, ograniczać własną egoistyczną skłonność do kierowania i zarządzania wszystkimi procesami. Jak twierdzi I. Klaja pojawia się moment, że właściciel powinien 
dobrowolnie zrezygnować z paternalistycznego zarządzania i powierzyć budowę i porządkowanie struktur organizacji, którą sam zbudował, specjalistom. I. Klaja mówi o tym procesie w następujący sposób: „Niewątpliwie zaangażowanie właścicieli wystarczyło, by zarządzać spółką na początku. My też do 2012 r. działaliśmy intuicyjnie. Brakowało nam strategii, struktur i narzędzi kontrolujących, bez których nie da się przejść na wyższy poziom" [Klaja, 2017, s. 23-24]. Potrzeba stałego wzmacniania i pozycjonowania marki własnej firmy podpowiada mu, że strategia obrana dla przyszłości to kreatywne i elastyczne dostosowywanie się do stale zmieniających się potrzeb i gustów klientów: „trzeba pamiętać, że rynek stale się zmienia i strategia, która sprawdza się dziś, może się jutro zdezaktualizować" [Klaja, 2017, s. 24].

Podobna ewolucję przeszła rodzinna firma Grycan. Z. Grycan i jego córka M. Grycan również zdecydowali się na oddanie celem stworzenia nowoczesnej struktury organizacyjnej ich firmy menedżerom zewnętrznym. Jak sami przyznaja, musieli zerwać ze starym myśleniem, że są w stanie sami kontrolować produkcję, jakość i sprzedaż swoich wyrobów, i podzielić się władzą z profesjonalistami. M. Grycan mówiła o tym procesie: „To firma była w rozkwicie. Ale potrzebowaliśmy narzędzi do tego, by te standardy wprowadzić i potem je egzekwować. Bo kiedy jest 5 czy 10 lodziarni, można je objechać i sprawdzić, czy wszystko działa, jak trzeba. A gdy rodzi się ich 50, to nie jest już takie łatwe" [Dębek, 2017, s. 23]. Zawsze jest jednak obawa wyrosła na podbudowie „starego myślenia” i zapatrzenia w przeszłość, ponieważ: „mieliśmy pewne obawy. Bo jednak to firma właścicielska i mamy do niej bardzo emocjonalny stosunek" [Dębek, 2017, s. 23].

„Twórcza destrukcja”, która stała się symbolem poszukiwania zmiany i odpowiadania na nia była impulsem do wprowadzenia nowej strategii rozwoju biznesu prowadzonego w branży kosmetycznej przez W. Inglota. Pod koniec dekady lat dziewięćdziesiątych zerwał on współpracę ze sklepami kosmetycznymi i rozpoczął budowanie własnej sieci dystrybucji i sprzedaży kosmetyków. Rodzina W. Inglota ocenia tę decyzję z perspektywy lat, jako „świetny ruch” [Dębek, 2018, s. 44]. Na podobne rozwiązanie zdecydował się producent rowerów Z. Sosnowski, który zerwał współpracę z firmą zajmującą się sprzedażą sprzętu sportowego i rozpoczął budowę własnej marki. Cena, która za to zapłacił, była wysoka. Musiał przeprowadzić restrukturyzację zatrudnienia, ograniczyć produkcję, zamknąc część działów produkcyjnych. Chwilowe osłabienie firmy, zaowocowało w następnych latach budową silnej na rynku marki Kross [zob. Kostrzewski, Miączyński, 2012, s. 52]. Zerwanie ze „starym myśleniem” spowodowało rewolucję w lokalnej firmie cukierniczej A. Sowy w Bydgoszczy. Właściciel cukierni, namówiony przez menedżerów pierwszego hipermarketu powstającego w Bydgoszczy, bez przekonania, ponieważ wszyscy lokalni cukiernicy odmówili, zdecydował się na uruchomienie punktu sprzedaży swoich wyrobów wraz z kawiarnią. Nie spodziewał się, że ten eksperyment otworzy mu drogę do sukcesu i budowy silnej na rynku lokalnym, a także w kraju, marki Sowa.

Solaris, wielkopolska firma produkująca autobusy, w 2018 r., jak wynika z wypowiedzi właścicielki S. Olszewskiej, wymaga rewolucji, aby wzmocnić jej markę. 
O dziedzictwie przeszłości mówi ona w następujący sposób: „daliśmy radę przez 21 lat rozwijać nasze przedsiębiorstwo własnymi siłami, nawet wtedy, kiedy mąż ciężko zachorował w 2012 roku. Krzysztof chciał, żebyśmy jako rodzina mieli stuprocentowa kontrolę nad Solarisem. I tak to funkcjonuje. Ale świat wokół nas szybko się zmienia. Wyścig z konkurencją staje się coraz trudniejszy i coraz bardziej kosztowny. Stąd pomysł na znalezienie inwestora" [Olszewska, 2018, s. 56]. Utrzymanie pozycji lidera, jak wyjaśnia S. Olszewska, wymaga szacunku dla dorobku firmy, którego nikt nie kwestionuje i zarazem racjonalnych decyzji podjętych natychmiast, aby w przyszłości marka świadczyła o rodzinie, która ją założyła. W decyzji właścicielki widoczny jest racjonalizm, który każe jej wznieść się ponad sentymenty i wskazane tytułowe „stare myślenie”. Jak mówi S. Olszewska „nasza fabryka jest za mała, potrzebne sa pieniądze na jej rozbudowę, nowe hale, zakup maszyn, robotyzację i automatyzację. (...) Inwestorzy z którymi rozmawiamy, bardzo szanują to, co osiagnęliśmy, i chcą z tego czerpać" [Olszewska, 2018, s. 58]. Dziedzictwo przeszłości, w wypadku tej firmy i wielu jej podobnych, stanowi ogromna wartość niematerialną, która jest dobrym tworzywem do budowy przyszłości firmy i wzmacniania jej marki.

\section{Podsumowanie}

Sukcesy firmy osiagnięte w przeszłości są fundamentem na którym zbudowana została jej bieżąca pozycja rynkowa i jej wartości. Przeszłość firmy, podobnie jak jej marka, która jest z nią integralnie związana, stanowi jej ważny zasób niematerialny. Jego wartość zależy od bogactwa tradycji ujętego w marce. Właściciel przedsiębiorstwa, bazując wyłącznie na zasobach własnej wiedzy i znając swoje błędy, buduje przyszłość firmy, zawsze spogląając w przeszłość. Inwestor, który jest skory nabyć przedsiębiorstwo, co ważne, jest gotowy zapłacić za pomyślną przyszłość firmy, o której świadczą wyłącznie jej sukcesy odniesione w bliższej i dalszej historii. Z tego tytułu K. Obłój podpowiada przedsiębiorcom, że „jeśli się nie zna i nie rozumie przeszłości organizacji i jej otoczenia, to zbudowanie przyszłości jest bardzo trudne. A przeszłość nie umiera i może być równie dobrze trampolina jak i barykadą na drodze do przyszłości i rozwoju firmy" [Obłój, 2017, s. 19].

Współczesne przedsiębiorstwa, w przeciwieństwie do tych wyrosłych z tradycji Polski Ludowej, nie odkreślaja własnej historii „grubą linią". Pozycjonując swoją markę, wzmacniają ją, odwołując się przy tym chętnie do przeszłości, do mitu założycielskiego. Przeszłość jest wartością niematerialną, która, podobnie jak marką, należy umiejętnie zarządzać, aby jej wartość rosła i dawała bardzo dobre referencje firmie.

\section{Literatura}

Archiwum Państwowe w Bydgoszczy, Bydgoska Fabryka Kabli, sygn. 19.

Archiwum Ministerstwa Skarbu Państwa, Fabryka Lin i Drutu Drumet S.A. we Włocławku, Realizacja nadzoru właścicielskiego. Korespondencja 1991-1994, List 
Prezesa Zarządu z dnia 14.10.1991 r. do Ministra Przekształceń Własnościowych Janusza Lewandowskiego, sygn. 3022/11.

Archiwum Ministerstwa Skarbu Państwa, Wniosek o przekształcenie w jssp, Pollena Bydgoszcz, sygn. 93/3.

Chamot J., 1973, Bydgoska Fabryka Kabli 1923-1973. Zarys historyczno-socjologiczny, Przedsiębiorstwo Wydawniczo-Handlowe Druków Akcydensowych, Bydgoszcz.

Chumiński J., 2010, Mentalne bariery rozwoju gospodarczego PRL (na przylkładzie pracowników przemystu), [w:] Modernizacja cayy pozorna modernizacja. Spoteczno-ekonomiczny bilans PRL 1944-1989, Chumiński J. (red.), GAJT, Wrocław.

Collins J., 2007, Od dobrego do wielkiego. Czynniki trwatego rozunoju i zuyyciestwa firm, MT Biznes, Warszawa.

Dębek K., 2017, Zbigniew Grycan z córk q, „Forbes”, grudzień.

Drucker P.F., 2004, Natchnienie i fart caylli innowacja i przedsiebiorczosść, Wydawnictwo Studio Emka, Warszawa.

Dunn E.C., 2008, Prywatyzujac Polske. O bobofrutach, wielkim biznesie i restrukturyzacji pracy, Wydawnictwo Krytyki Politycznej, Warszawa.

Hampden-Turner Ch., Trompenaars A., 2006, Siedem kultur kapitalizmu, Oficyna Ekonomiczna, Kraków.

Kamosiński S., 2007, Mikroekonomiczny obraz przemystu Polski Ludowej w latach 19501980 na prayktadzie regionu kujawsko-pomorskiego, Wydawnictwo Poznańskie, Poznań.

Kamosiński S., 2009, Modernizacja oparta na strategii naśladownictwa. Polski przemyst w latach 1950-1989 a import i eksport mysli technicznej, [w:] Miedzy zacofaniem a modernizacja. Spoleczno-gospodarcze problemy ziem polskich na przestrzeni wiekón, Kościk E., Głowiński T. (red.), GAJT, Wrocław.

Kamosiński S., 2013, Pojazdy Syynowe PESA Bydgoszcz SA w Bydgoszcry. Strategia budowy marki: PESA Bydgoszcz. SA, [w:] Przedsiebiorstwa podczas przemian systemonych w Polsce przetomu XX $i$ XXI wieku. Sukcesy i porą̇ki rynku, Czechanowski P., Grala D. (red.), Wszechnica Edukacyjna i Wydawnicza „Verbum”, Poznań.

Kamosiński S., 2014, Marka produktón w okresie transformacji gospodarki polskiej (analiza empiryczna), „Studia z Zakresu Prawa, Administracji i Zarządzania Uniwersytetu Kazimierza Wielkiego w Bydgoszczy", nr 6.

Kamosiński S., 2015, Przedsiebiorstwa w przebudowie. Prywatyzacja i restrukturyzacja przedsiebiorstw kujawsko-pomorskich w latach 1990-2004, Wydawnictwo Uniwersytetu Kazimierza Wielkiego, Bydgoszcz.

Klaja I., 2017, Jak zbudowatem marke 4F, „Forbes”, czerwiec.

Kostrzewski L., Miączyński P., 2012, Łowcy milionów, AGORA SA, Warszawa.

Kunach B., 1991, Pollena zapomniała o recesji, „Gazeta Wyborcza”, 14.08.1991 r.

Lipiński E., 1981, Problemy pytania watpliwości. Z warsðtatu ekonomisty, PWE, Warszawa.

$\mathrm{Na}$ ścię̧ce do prywatyzacji zatryymat nas strach..., 1993, z tymczasowym kierownikiem „Zachemu” Jerzym Ossowskim rozmawia Michał Żurowski, „Promocje Pomorskie", nr 5.

Nowoczesny tabor: jakosśc na szynach, 2007, „Miesięcznik Gospodarczy Nowy Przemysł”, 26.09.2007 r., www.gospodarka.gazeta.pl. 
Obłój K., 2017, Praktyka strategii firmy jak zarz̨adzać pržesz̧ościa, radzić sobie z. teražniejsqościq i tworzyó prayszłość, Poltext, Warszawa.

Olins W., 2009, Podrecznik brandingu, Instytut Marki Polskiej, Wrocław.

Olszewska S., 2018, Tak szukam inwestora. Solaris potrzebuje kapitatu, wywiad przeprowadził E. Stankunowicz, „Forbes”, maj.

Szanujac tradycje, šjjemy teraźniejszościa i prayszłościa, 2011, z Tomaszem Zaboklickim, prezesem PESA Bydgoszcz SA rozmawiała Dorota Bartoszek, „Rynek Kolejowy", nr 4.

Teczlea obiektowa „Naprawa”, Instytut Pamięci Narodowej Delegatura w Bydgoszczy, sygn. IPN By O/1283, t. 7.

Welch J., Welch S., 2012, Winning znaçy znycieżać, Wydawnictwo Studio Emka, Warszawa. 